\title{
Grammatical Error of EFL Senior High School Learners in Writing: A Review of Language Interference Studies
}

\author{
Vidya Mandarani* \\ University of Muhammadiyah Sidoarjo, Indonesia \\ e-mailvmandarani@umsida.ac.id \\ *corresponding author
}

\section{Article History}

Received: 27 January 2020

Reviewed: 10 February 2020

Accepted: 19 March 2020

Published: 30 April 2020

\section{Highlights}

- The most grammatical errors are the improper use of verb and copula 'be' omission.

- The fact that first language is crucially influential in second or foreign langua acquisition is proven by the en of grammatical errors as a form of language interference.

\begin{abstract}
Considering the importance of English as one of pivotal courses in compulsory education, Indonesian students are liable to error produced during their language acquisition phase. This paper's aim is to unveil what is the most frequent language interference presents in students' writing that centered upon grammatical context, along with its correlative factors and the very process of interference, encountered by senior high school learners within their second or foreign language acquisition phase. This was carried through library research, which relies towards other articles from researchers, under the same concerns of language interference, as the main objective. There are 4 researches taken as primary sources that issued or published within the last 5 years. The findings of each studies are assessed in gaining a better insight for this paper's inquiries. From the analysis, the outcomes proved that the errors mostly occurred were caused by interference came in a form of incorrect use of verb as well as copula 'be' omission during sentence composing. Such errors were not solely caused by the entity of language interference alone, yet also compounded by the lack of motivation in using English as a communication medium both inside and outside the classroom activity.
\end{abstract}

Keywords: Grammar, Error, Language Interference, Writing

\section{Introduction}

Centuries ago, Commonwealth dominance over the vast amount of colonial soils brought English as our current lingua franca, a worldwide intermediary. Corresponding to such fact, Burns (2004) inevitably agreed that English is, by far, the most successful language in this world with approximate users around 840 million to 1.34 billion. As a civilization that possess an enormously diverse culture, most Indonesian who were gifted with around 300 native languages apart from Indonesian language as its sole unifying language do not use English as their daily communication amongst themselves (Alek, 2010). Most Indonesians, if not all, use Indonesian language within their both casual and formal interaction. However, Mapiasse \& Sihes noticed that the flow of globalized world, which demanded a convenience of lingua franca, apparently shaped the landscape of education practice and policies of English language teaching (ELT) in Indonesia (Mappiasse \& Sihes, 2014). Hence, ELT agendas have long been an integral part within Indonesian education system.

Contrary to English that originated from a monolingual society, these native languages or even Indonesian language that possessed by many Indonesians have different linguistic traits that later raised peculiar difficulties for most students of any ages in learning new language. One of the well-known hindrances faced by these language learners is in structural section, or grammar to be precise. As an eminent obstacle, grammar often obstructs learners' proficiency in mastering a particular language. In Indonesia, learning English mostly falls under the 
jurisdiction of foreign language (L3) acquisition, or FLA, since Indonesians first language in daily basis (L1) are mostly their mother tongue while their second language (L2) is Indonesian language or vice versa; hence the term of Teaching English as Foreign Language (TEFL). This status quo is in line with L3 definition from Richards et al., which is a language that is taught in either formal or informal education, yet has little to none uses in the corresponding nation, country, or region as an instruction medium or as a communication language (Richards, Platt, Weber, \& Inman, 1986).

TEFL agenda encompasses an experience called as language transfer that later became a prominent source of language interference, which further leads to errors that made by learners themselves during language acquisition phases. Saville-Troike further exclaimed that there are two major kinds of language transfer: positive and negative (Saville-Troike, 2012). The classification itself lies upon whether learners' L1 is useful in assisting target language (TL) acquisition, either L2 or L3. For example, one might be considered lucky when he possessed French as his L1, while learning for Italian as their L2 or L3, since both languages share many linguistic similarities. Such is the example of positive transfer. However, when one's L1 mostly obstructs his TL acquisition, negative transfer occurred. This is because of a distinct linguistic characteristic between the corresponding language, like Indonesian and English languages for instance. This negative transfer is what most linguists regarded as language interference, which often contributes towards error production from language learners.

Congruently, Lightbown \& Spada highlighted that the underlying difference in linguistic traits between L1, L2, and L3 is the trigger of interlanguage (Lightbown \& Spada, 2006). As previously mentioned, interference is possible when source language (SL) does not share similar language components with TL. When students are expected to produce a desired result in TL (L3 in this case), they might come across an error since Indonesian students are generally accustomed to Indonesian language or their mother tongue. Based on this issue, researcher intended to carry a library research in investigating language interference in grammar for EFL senior high learners from 4 different articles or studies with the same concern. The selection of senior high grade itself is quite crucial since high school is the apex of compulsory education, which equally means that most learners should have able in properly utilizing English grammar to produce the desired result in TL. These articles or studies are focused upon students' writing, since error development could only be observed in productive language skills, such speaking or writing.

The outcomes of this review paper are expected to give a better insight upon what kind of language interference that mostly occurred in form of grammatical error, along with its process as well as significant factors that influence the emergence of language interference; which in turn, will provide a better insight for ELT domain, specifically for teachers and lecturers alike. However, suggestions and further corrections are more than welcome, considering there might be another hidden insight of language interference in form of grammatical error within a set of different language other than Indonesian and English languages pair. 
Before delving any further, it is necessary to distinguish such synonymous words like error and mistake. Both terms indeed came with a same 'true or false' value under the 'wrong' side. However, in addressing this matter, Ellis pointed out that mistakes generally refer to a faulty performance due to an inadvertent cause that is out of learners' control (Ellis, 2012). For instance, learners made mistake in writing a text in TL due to fatigue or loss of focuses. In that regard, Tarone et al. signifies that no matter how proficient someone in their SL or TL, mistake is a possible encounter (Tarone, Bigelow, \& Hansen, 2013). Contrary to this, errors are something emerged due to the lack of proper performance requirements, like knowledge or experience. Similar to mistakes, most learners are unaware of their errors. The only way to tell a difference of these two terms is that we may correct a mistake almost directly once we found one, though the same cannot work for error. Learners may unable to correct an error immediately and mostly left unaware of it until pointed out due to their own incapability.

In addition to speaking, Fromkin et al. explained that writing, as a productive skill, is deemed as the highest level of competence, since it requires a proper operation that is affected by writer performance in other 3 language skills (speaking, listening, and reading) (Fromkin, Rodman, \& Hyams, 2003). Similarly, Brown also claimed that, apart from being essential, writing is also the most difficult skills of the remaining three, even in one's native language (Brown, 2007). Writing comprises of 5 (five) diverse abilities that ought to be possessed by any language learners. These are TL knowledges, proper usage of punctuations, creativity, proper idea transmittance, as well as a stylistic sense. Considering these complex requirements, it is no wonder that errors were made by EFL learners. Moreover, the discourse of writing itself is inseparable with grammar. Hirai et al. emphasized grammar as a mean of sentence organizing in attempt to create a meaningful use of language (Hirai, Borrego, Garza, \& Kloock, 2013). Likewise, Nurhayati added that every student has his/her own grammatical knowledge from learner's SL that is likely influential towards L2 or L3 acquisition (Nurhayati, 2015).

Further, a mastery of TL grammar system is an upmost importance, since a proper knowledge of grammar roughly equals to the minimum errors made by the correlated learners and the lack of it would simply leads to a condition called linguistic constraint. An error created from such condition is also called as grammatical interference. In essence, interference is seen as both psychological and sociolinguistic phenomenon. Further, Selinker asserted that language interference includes 5 (five) elements. These are interlingual transfer, overgeneralization, excessive emphasize on grammar, improper learning strategies, and incorrect communication strategies (Selinker, 1972). Also, interlanguage case might happen upon all linguistic level, as in phonology, morphology, syntax, lexical or semantic. However, only those that occurred in both morphological and syntactical levels that can be called as grammatical interference or rules deviation.

\section{Methodology}

As briefly mentioned before, library research is the backbone of this study. Mann emphasized that library research is a research model that comprises of at least 6 corresponding keys (Mann, 1993). These are keyword searches, subject searches, probe for recent scholarly articles, books or publication, citation searches, searches of direct people source, as well as systematical browsing. Researcher regarded this model as one of the appropriate approaches in answering this paper question. There are 4 (four) recent articles that were published under 
similar concern of language interference. The first paper entitled "Interlanguage: Grammatical Errors on Students' Recount Texts (A Case Study of First Year of MAN 2 Banjarnegara in the Academic Year 2014/2015)" authored by Nurhayati (2015). The second paper entitled as "Indonesian Interference in Students' Writing" authored by Irmalia (2016). The third one is "First Language Interferences into English Writing Skill of the $12^{\text {th }}$ Grade Students of SMA Negeri 1 Kupang in Academic Year 2017/2018" by Djedelbert Lao (2017). The last source is from Jem, et al. (2018) under the title "Mother Tongue's Interference in Manggaraian Students' English Writing of Senior High Schools Students in Langke Rembong Subdistrict”.

\section{Findings and Discussion}

\section{Findings}

Prior to thorough screening and probing, researcher found that the outcomes of these 4 (four) articles. The corresponding researchers from these papers already sorted out the errors category based on the frequency of each grammatical error occurred during learners' writing process, mentioned in detail as follow:

\section{Improper Use of Tense}

According to a theory from Bates et al. (1993) as cited by Irmalia (2016), this form of error is classified as global error, which means that it's an error that mostly occurred in Indonesian senior high learners' circle. One of the examples is the overlooked '-ed' suffix of regular verb or the addition of '-ed' suffix for irregular verb within typical recount text. As for uttering sentences of a fact or routine, they mostly dealt with improper diction. For instance, instead of "I boil water", learners wrote "I cook water" since in Indonesian language, there is ambiguous line between 'memasak' and 'merebus' terms; as well as "I love English from when I sitting in junior high school" instead of "I love English since I was sitting in junior high school."

From these examples, it's eminent that the cause of learners' errors are mostly because of their L1 pattern, which is either Indonesian language or mother tongue, which then they forcibly tried to conceptualize such pattern into English (L3) by relying into textual translation with the aid of dictionary. There are around 3 processes of interlanguage appear in such scheme. The first is overgeneralization, which influences the negligence of context in applying the proper verb or tense; the second is the awkward language learning strategy, in which students' reliance upon textual translation of dictionary; while the last is systematicity, or their knowledge deficiency upon TL linguistic trait, specifically in English grammar.

\section{Omission of 'be' auxiliaries}

This second kind of errors is also called as local error, which is an error that frequently appeared during phrase or sentence composing. For instance, "my friends very nice, they always help me" in which 'are' is unconsciously omitted. Reflecting back at learners L1, this error is quite common considering the absent rule of 'to be' in Indonesian language. There are around 3 (three) interlanguage process involved in such case. These are permeability, which often reflects both learners' native language overgeneralization and transfer; language transfer that has been mentioned previously; and transfer of training. 


\section{Discussion}

The cause of these two kinds of error unveiled in the previous paragraph that are triggered by the influence L1 linguistic traits, which in this case is the grammar set of Indonesian language. Though, from 4 (four) articles that researcher reviewed, one of these mentioned local language (Manggaraian) as learners' L1 instead of Indonesian language. However, both native and Indonesian languages often share the same pattern and linguistic traits. Which is why many students' writing are being influenced by Indonesian language-styled pattern. Both Djedelbert Lao (2017) and Jem et al. (2018) confirmed that learners' mental image of L1 plays a significant amount of influence in deviating their TL (English) manifestation. Simply said, most students use Indonesian language pattern as a stopgap in producing written phrases or sentences in TL. This is why most interference occurred in both morphological and syntactical (grammar) level, knowing that many learners unknowingly depended upon textual translation without paying enough attention into the context, which later produced an output that is inappropriate in grammatical sense of TL.

With that being said, L1 acquisition has the largest impact upon learners' language knowledge of both morphology and syntax. This is also the reason on why there are only a few grammatical errors occurred in morphological and lexical, let alone philological level. In attempt to validate this, researcher found an article carried with the same study. It is a paper authored by Sawalmeh (2013) who took his research in discovering errors made by Saudis learners in writing English essays. He later found that most students also showed both morphological and syntactical errors in detailed grammatical forms, like word orders, plural or singular form, subject-verb agreement, verb tense, double negatives articles, preposition, as well as other writing elements like punctuation, capitalization, and spelling, which was caused by learners' L1 (Arabic) linguistic patterns.

\section{Conclusion}

From these exposures, it is confirmed that the answer of this paper lies in misused tenses as the most frequent grammatical error found in all of 4 (four) selected articles under the same topic; followed by the omission of to be. This is quite understandable knowing that time-based verb is virtually non-existent in grammatical rule of learners' L1 or L2. Such linguistic disadvantage is further aggravated by the lack of exercises and practices conducted during, as well as learners' dependency towards dictionary and other students' answer will only worsen the presence of language interference.

\section{References}

Alek, H. A. (2010). Bahasa Indonesia untuk Perguruan Tinggi. Jakarta: Kencana Prenada Media Group. Brown, H. D. (2007). Principles of Language Learning and Teaching (5th ed.). Pearson Longman.

Burns, A. (2004). Teaching English from Global Perspective: What Are the Implication in SE Asia. Thirteenth International Symposium on English Teaching: Trends in Asian ELT-Theory and Practice, 1-15. Taipei.

Djedelbert Lao, Y. A. (2017). First Language Interferences into English Writing Skill of the $12^{\text {th }}$ Grade Students of SMA Negeri 1 Kupang in Academic Year 2017/2018. Intenational Journal of Research-Granthaalayah, 5(12), 33-44. https://doi.org/10.5281/zenodo.1133564

Ellis, R. (2012). Understanding Second Language Acquisition. Shanghai: Shanghai Foreign Language Education Press.

Fromkin, V., Rodman, R., \& Hyams, N. (2003). An Introduction to Language (7th Ed.). Retrieved from http://relin.letras.ufmg.br/shlee/Fromkinch1.pdf 
Vidya Mandarani, Tell : Teaching of English Language and Literature Vol. 8, No. 1, 1 - 6 Doi: http://dx.doi.org/10.30651/tell.v8i1.4158

Hirai, D. L. C., Borrego, I., Garza, E., \& Kloock, C. T. (2013). Academic Language/Literacy Strategies for Adolescents: A "How-To" Manual for Educators. London: Routledge.

Irmalia, M. (2016). Indonesian Interference in Students' Writing. English Education Journal (EEJ), 7(4), 496-508. Retrieved from http://jurnal.unsyiah.ac.id/EEJ/article/view/5535/4569

Jem, Y. H., Semana, I., Guna, S., \& Darong, H. C. (2018). Mother Tongue's Interference In Manggaraian Students' English Writing of Senior High Schools Students in Langke Rembong Subdistrict. Jurnal Pendidikan Dan Kebudayaan Missio, 10(1), 70-78.

Lightbown, P. M., \& Spada, N. (2006). How Language Are Learned (3rd Ed.). Oxford: Oxford University Press.

Mann, T. (1993). Library Research Models: A Guide to Classification, Cataloging, and Computers. Oxford: Oxford University Press.

Mappiasse, S. S., \& Sihes, A. J. (2014). Evaluation of English as a Foreign Language and Its Curriculum in Indonesia: A Review. English Language Teaching, 7(10), 113-122. https://doi.org/10.5539/elt.v7n10p113

Nurhayati, I. (2015). Interlanguage: Grammatical Errors on Students' Recount Texts (A Case Study of First Year of MAN 2 Banjarnegara in the Academic Year 2014/2015). ELT Forum: Journal of English Language Teaching, 4(1), 1-6.

Richards, J., Platt, J., Weber, H., \& Inman, P. (1986). Longman Dictionary of Applied Linguistics. RELC Journal, 17(2), 105-110. https://doi.org/10.1177/003368828601700208

Saville-Troike, M. (2012). Introducing Second Language Acquisition. England: Cambridge University Press.

Sawalmeh, M. (2013). Error Analysis of Written English Essays: The Case of Students of the Preparatory Year Program in Saudi Arabia. English for Specific Purposes World, 14(40).

Selinker, L. (1972). Interlanguage. International Review of Applied Linguistics, 10, 209-231.

Tarone, E., Bigelow, M., \& Hansen, K. (2013). Literacy and Second Language Oracy. Oxford: Oxford University Press. 